DOI: https://doi.org/10.24297/ibt.v8i0.8503

\title{
Induction of High-Frequency Callus with an Elite Cotton (Gossypium Hirsutum L.) from Côte d'Ivoire
}

\begin{abstract}
Affoue Sylvie Rachelle N'GUESSAN ${ }^{1 *}$, Koutoua AYOLIE ${ }^{1}$, Sopie Edwige Salomé YAPO ${ }^{1}$, Yao Kouakou Francois KONAN ${ }^{1}$, Achi Laurent N'CHO${ }^{2}$, Kouakou Désiré N'GORAN², Dramane KONE², Yatty Justin KOUADIO'1, Tanoh Hilaire KOUAKOU²
\end{abstract}

${ }^{1}$ Université Jean Lorougnon Guédé, UFR Agroforesterie, BP 150 Daloa, Côte d'Ivoire

2 Université Nangui Abrogoua, UFR Sciences de la Nature, 02 BP 801 Abidjan 02, Côte d'Ivoire nguessansylvie322@gmail.com

\begin{abstract}
In cotton, factors such as carbon sources, hormonal combination, and type of explant influence the responses to callus induction. In this study callus induction was optimized to get high-frequency callus in cotton. Different carbon sources were tested, and among them, glucose at $3 \%$ was found to be the best carbohydrate in callus induction. Culture medium supplemented with 2,4-D $\left(0.1 \mathrm{mg} \cdot \mathrm{L}^{-1}\right)$ and $\mathrm{KIN}\left(0.5 \mathrm{mg} \cdot \mathrm{L}^{-1}\right)$ gave a high callogenesis response, unlike other hormonal combinations. With explants, hypocotyl $(72.93 \%)$ appeared easier to induce callus than cotyledon (48.75\%) following root (37.5\%). So, carbone sources, hormone, and their concentration affect significantly callus induction. The highest frequency of callus induction was then observed when hypocotyl explants were cultured on medium supplemented with $0.1 \mathrm{mg} \cdot \mathrm{L}^{-1}$ of $2,4-\mathrm{D}$ in combination with $0.5 \mathrm{mg} \cdot \mathrm{L}^{-1}$ of KIN and $3 \%$ glucose. The induced-callus obtained were friable and of high quality. The other types of combinations resulted in the formation of compact callus with sometimes roots emerging from it. The present study may provide an efficient protocol to improve the callogenesis responses by adjusting the carbohydrates, the hormonal regime, and the type of explant to be cultured for a high-frequency callus induction of the Y331B-R5 cotton cultivar.
\end{abstract}

Keywords: Cotton, Callus, Carbohydrate, Explant, Growth Regulator.

Abbreviations: 2,4-D: 2,4-dichlorophenoxyacetic; NAA: naphthalene acetic acid; IBA: indol-3-butyric acid; BAP: benzyl amino purine; KIN: kinetin; TDZ: thidiazuron; CM: callus medium; MSB: MS basal medium with vitamins B5.

\section{INTRODUCTION}

Cotton, a tropical plant, is among the most important crop in the world. The genus Gossypium includes some 50 species, and only four of them are currently grown for the fibers and seeds production [1]. Initially produced for the fibers in the textile industry, cotton is also grown for the seed oil, which is the main oil consumed in the Sahelian countries [2]. Overall, the United States, China, India, and Pakistan lead with more than $80 \%$ of world cotton production [3]. With an output of 412.646 tons in 2017-2018, Côte d'Ivoire is the fourth producer in south of Sahara, hereafter Mali, Burkina Faso, and Benin [4]. In Côte d'Ivoire, cotton is the fourth export product and contributes to $1.7 \%$ of Gross Domestic Product (GDP). The incomes generated by cotton crop reach more than 100 billion CFA francs per year and supports about 3.5 million people $[5,6]$. However, Ivoirian cotton production is subjected to several constraints resulting in lower yield. Causes are multiple, but, pest pressure is by far the most important as it sometimes resulted in $30 \%$ loss of production [7]. Pesticides and phytosanitary products advised as solution to parasitic pressure have polluted environment and plant material. So, other more environmentally conscious methods have been introduced to improve performance. Among these, in vitro culture through its various techniques like somatic embryogenesis permit not only to produce plant material healthy and performing to improve production $[8,9]$, but it is also species 
improvement method. Indeed, somatic embryos can develop resistance to any diseases [10]. In addition, callogenesis is an important step for protoplast fusion [11, 12].

However, the success of somatic embryogenesis requires many control of factors influencing somatic embryos induction. Thus, the medium components and explant type are substantial factors who influence indirect embryogenesis [13]. This study contributes to the improvement of cotton regeneration techniques and highlights the influence of the composition of culture medium and explant type on cotton callogenesis.

\section{MATERIAL AND METHODS}

\subsection{Seeds material}

Seeds of cotton cv. Y331B-R5 was obtained from Ivorian Textile Development Company (Korhogo, Côte d'Ivoire, West Africa). The seeds surrounded by fibers were delinted by using commercial sulfuric acid $\left(100 \mathrm{~mL}^{\mathrm{Kg}} \mathrm{K}^{-1} \mathrm{of}\right.$ seeds). Acid was added to the seeds contained in a glass jar and stirred with a stick until the fibers vanish for $1 \mathrm{~min}$. Subsequently the seeds were washed under running tap water for $15 \mathrm{~min}$ and finally washed by distilled water for 5 min. Following rinsing with tap water to completely dismiss the sulfuric acid delinted seeds were dried in the open air and constitute seed material used for the experiments.

\subsection{Culture medium and conditions of culture}

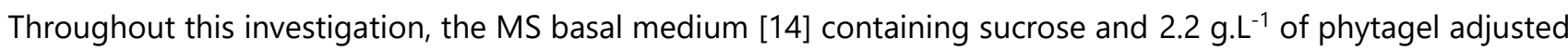
to $\mathrm{pH} 5.8$ was used. Unless otherwise stated, growth hormones were always added before autoclaving the medium which was done at $121^{\circ} \mathrm{C}$ under 1 bar pressure for $20 \mathrm{~min}$. All cultures' media were incubated in a growth room under a $12 \mathrm{~h}$ photoperiod with cool white fluorescent light at 2000 lux of intensity, and the temperature was maintained at $28 \pm 2{ }^{\circ} \mathrm{C}$ with $70 \%$ relative humidity.

\subsection{Seeds surface disinfection and in vitro germination}

The seeds were transferred under a laminar airflow and surface sterilized by dipping in 70\% (v/v) ethanol for 1 $\min$. The seeds were disinfected thoroughly in $2.4 \%(\mathrm{v} / \mathrm{v})$ hypochlorite sodium-containing $3-4$ drops of Tween-20 for 30 min with intermittent shaking. Finally, the seeds were rinsed with sterilized distilled water five times. The disinfected seeds were dipped and kept in sterile distilled water during $48 \mathrm{~h}$ for coats softening. Seeds without coats were inoculated on half-strength MS [14] basal medium supplemented with vitamins B5 [15] in test tubes for seedling formation. Seeds were incubated in dark condition for 2-days and then transferred under light/dark photoperiod for 5-days. The in vitro grown seedlings of cotton were used as the source of explants.

\subsection{Callus induction and growth}

Callus induction and growth were performed on MS basal medium with vitamins B5 (MSB) supplemented with 2,4 dichlorophenoxyacetic (2,4-D), naphthalene acetic acid (NAA), indol-3-butyric acid (IBA), benzylaminopurine (BAP), kinetin (KIN) and thidiazuron (TDZ), sugars such as glucose, fructose, maltose and sucrose. Cotyledon, hypocotyl, and root segments from in vitro grown seedlings were used as explants. The choice of growth regulators, sugars and explants for different experiments depends on the objective to be achieved. Eight culture pots each containing four explants were used by treatment. The experiment was designed in a complete randomized device with triplicate.

\subsubsection{Effect of sugar type}

To test the effect of sugar types on callus induction, different types of carbon sources (sugars), including glucose, fructose, maltose and sucrose at $30 \mathrm{~g} \cdot \mathrm{L}^{-1}$ were supplemented to callus medium (CM) constituted of MSB medium supplemented with $0.1 \mathrm{mg} \cdot \mathrm{L}^{-1} 2.4-\mathrm{D}$ and $0.5 \mathrm{mg} \cdot \mathrm{L}^{-1} \mathrm{KIN}$ [16-18].

After determining the best sugar 
type, the best concentration of sugar was examined at concentration of 20 to $50 \mathrm{~g} \cdot \mathrm{L}^{-1}$. Cotyledons from 7-dayold-grown sterile seedlings were used as explants. Cotyledon measuring about $5 \times 5 \mathrm{~mm}$ was cut with a sterile scalpel in a laminar flow cabinet and were inoculated on the CM medium for 4-weeks. The best sugar and its best concentration will be retained for further experiments.

\subsubsection{Effect of growth regulators}

Various concentrations of six hormones solutions were prepared and added to $\mathrm{CM}$, medium containing the best sugar at its best concentration. Three auxins such as 2,4-D, NAA, IBA and three cytokinins such as BAP, KIN, and TDZ were used at $0.1,0.5,1.0$ and $1.5 \mathrm{mg}^{-\mathrm{L}^{-1}}$. Cotyledon pieces $(5 \times 5 \mathrm{~mm})$ were used as explants. In total, 12 hormone combinations were carried out with cytokinins. The hormone regime which promoting the best callogenesis was retained for the next experiment.

\subsubsection{Effect of explants types}

Cotyledon pieces ( $5 \times 5 \mathrm{~mm}$ ), hypocotyl sections ( $5 \mathrm{~mm}$ length), and root segments ( $5 \mathrm{~mm}$ length) of day-old in vitro plantlets were used in this study to evaluate the effect of explant type on callus induction. Explants were cut with a sterile scalpel under a laminar flow cabinet and were placed on MS medium containing best sugar with its best concentration and best hormone regime for 4-weeks.

\subsection{Statistical analysis}

Statistical analysis was performed using the STATISTICA 7.1 software. Data were subjected to analysis of variance (ANOVA) using STATISTICA 7.1 software at 5\%. For parametric values, the Newman-Keuls test was used to means comparison, while, for nonparametric values, the Kruskal-Wallis test was used.

\section{RESULTS}

\subsection{Effect of carbon source on callus induction}

The results of the carbon source effect were recorded in Table 1. These results showed that there is a significant effect between sugar type on callus induction. In fact, the bursting time was significantly influenced by the sugar type. Thus, the fastest bursting time ( 7 days) was noticed with glucose followed by fructose and maltose (15 days). While sucrose, gave the longest bursting time (20 days). These results also revealed that glucose produced the highest rate of callus $(64.05 \%)$ in front of fructose $(50.13 \%)$ while sucrose induced the lowest rate of callogenesis (27.32\%). Likewise, there are significantly different between the weights of fresh and dry material.

Table 1. Influence of carbon source on cotton callus induction

\begin{tabular}{lccccccc}
\hline $\begin{array}{l}\text { Carbone } \\
\text { source }\end{array}$ & $\begin{array}{c}\text { BT } \\
\text { (Day } \\
\text { ) }\end{array}$ & Cl (\%) & FW (mg \pm s) & DW (mg \pm s) & PR (\%) & Color & Texture \\
\hline Glucose & 10 & $64.05 \pm 4.25 \mathrm{a}$ & $17.25 \pm 4.90 \mathrm{a}$ & $2.87 \pm 0.76 \mathrm{a}$ & $95.31 \pm 8.13 \mathrm{a}$ & $\mathrm{Green}$ & $\mathrm{Fr}$ \\
\hline Sucrose & 7 & $27.32 \pm 4.86 \mathrm{~d}$ & $3.68 \pm 1.08 \mathrm{~b}$ & $0.05 \pm 0.01 \mathrm{c}$ & $25.12 \pm 5.04 \mathrm{c}$ & Yell & $\mathrm{Fr}$ \\
\hline Fructose & 5 & $50.13 \pm 5.05 \mathrm{~b}$ & $10.11 \pm 3.05 \mathrm{ab}$ & $1.76 \pm 0.38 \mathrm{~b}$ & $38.26 \pm 7.29 \mathrm{~b}$ & White & $\mathrm{Fr}$ \\
\hline Maltose & 5 & $41.16 \pm 4.61 \mathrm{c}$ & $4.59 \pm 1.33 \mathrm{~b}$ & $0.46 \pm 0.15 \mathrm{bc}$ & $30.70 \pm 7.45 \mathrm{~b}$ & Brow & $\mathrm{Fr}$ \\
& & & & & & $\mathrm{n}$ & \\
\hline
\end{tabular}


In a column, means followed by the same letter are not significantly different at 5\%; BT: Bursting time; D: Day; IR: Induction rate; FW: Fresh weight; DW: Dry weight; PR: Proliferation rate; Gr: Green; Yell: Yellow; Br: Brown; Fr: Friable.

The highest weights of fresh and dry material were obtained on glucose supplemented medium (17.25 and 2.87 $\mathrm{mg}$, respectively). Sucrose induced the lowest fresh weight $(3.68 \mathrm{mg})$ and dry weight $(0.05 \mathrm{mg})$. The proliferation rate estimation showed that sugar type significantly influenced callus proliferation $(95.31,38.26,30.70$ and $25.12 \%)$ for the glucose, fructose, maltose, and sucrose respectively. All the sugar types induced friable callus. However, the most friable callus was obtained with glucose and this callus was green (Figure 1).

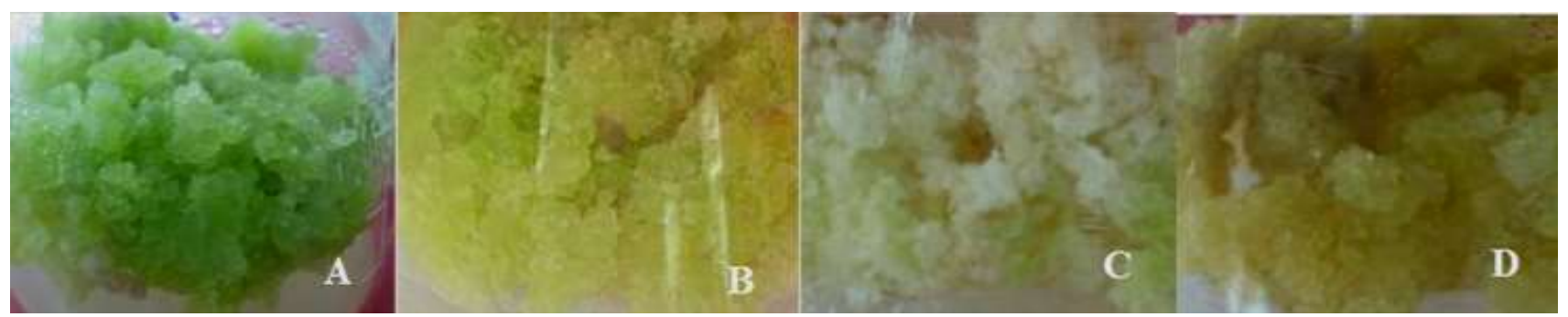

Figure 1. Callus derived from cotyledon explants of cotton in MS medium supplemented with carbohydrate A: glucose; B: sucrose; C: fructose; D: maltose

\subsection{Effect of glucose concentration on cotton callus proliferation}

The results of glucose concentration of callus induction are presented in Table 2 and shown that glucose levels have significantly affected $(p<0.001)$ callus proliferation. Indeed, the bursting time decreases with the increase of glucose concentration of culture medium. The results also showed that the induction rate, the fresh and dry weights increased when the glucose concentration increased in the culture medium. However, glucose at $5 \%$ induced the highest induction rate (75.52\%) and the highest fresh and dry weights (18.95 and $2.29 \mathrm{mg}$ respectively). Low concentrations of glucose ( 2 and $3 \%$ ) produced a friable, white and green callus. While high glucose levels have induced a little friable callus and present a slight browning (Figure 2).

Table 2. Impact of glucose concentration cotton callus induction

\begin{tabular}{cccccccc}
\hline Glu & $\begin{array}{l}\text { BT } \\
\text { (D) }\end{array}$ & IR & FW & DW & PR & Color & Texture \\
$\mathbf{( \% )}$ & & $(\%)$ & $(\mathbf{m g} \pm \mathbf{~ s )}$ & $\mathbf{( m g ~} \pm \mathbf{s})$ & $\mathbf{( \% )}$ & & \\
& & & & & & & \\
\hline $\mathbf{2}$ & 10 & $47.5 \pm 2.5 \mathrm{c}$ & $3.95 \pm 1.08 \mathrm{~d}$ & $0.65 \pm 0.21 \mathrm{c}$ & $32.89 \pm 7.75 \mathrm{c}$ & white & friable \\
\hline $\mathbf{3}$ & 7 & $62.07 \pm 2.2 \mathrm{~b}$ & $15.22 \pm 4.39 \mathrm{c}$ & $1.39 \pm 0.66 \mathrm{~b}$ & $51.67 \pm 9.04 \mathrm{ab}$ & green & friable \\
\hline $\mathbf{4}$ & 5 & $66.17 \pm 2.3 \mathrm{~b}$ & $17.11 \pm 4.3 \mathrm{ab}$ & $1.42 \pm 0.42 \mathrm{~b}$ & $63.01 \pm 9.32 \mathrm{ab}$ & brown & lit fr \\
\hline $\mathbf{5}$ & 5 & $75.25 \pm 0.1 \mathrm{a}$ & $18.95 \pm 5.47 \mathrm{a}$ & $2.29 \pm 0.69 \mathrm{a}$ & $77.37 \pm 9.11 \mathrm{a}$ & brown & lit fr \\
\hline
\end{tabular}


In the column, means with the same letters are not significantly different at 5\%; Glu: Glucose BT: Bursting time; D: Day; IR: Induction rate; FW: Fresh weight; DW: Dry weight; PR: Proliferation rate; Lit fr: Little friable.

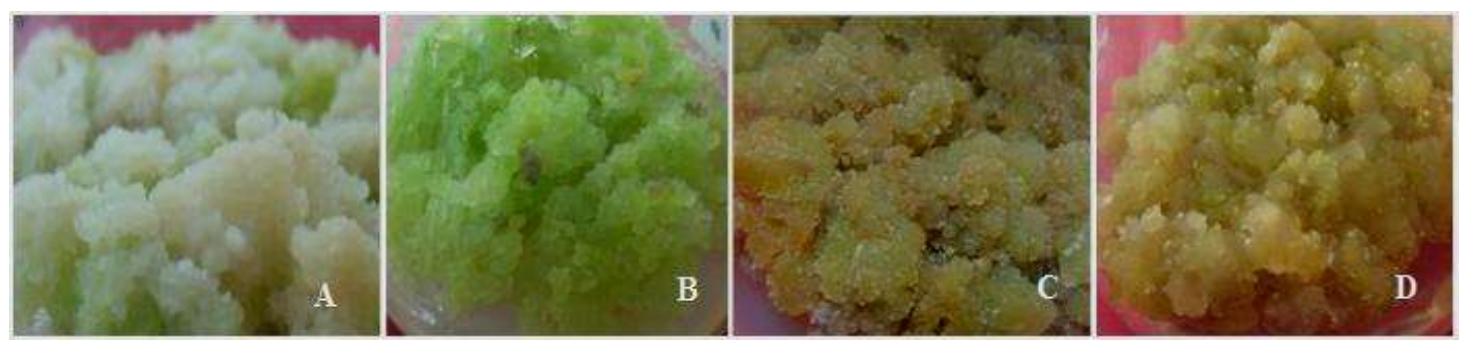

Figure 2. Callus appearance induced with different glucose concentrations of cotton cotyledon A: $2 \%$ glucose; B: $3 \%$ glucose; C: $4 \%$ glucose; D: $5 \%$ glucose.

\subsection{Effect of auxins and their concentration on callogenesis}

In this study, three auxins at different concentrations were tested on cotton callogenesis. The results showed a significant difference between auxins and their concentrations on callogenesis. Indeed, only the low concentrations of 2,4-D (0.1 and $\left.0.5 \mathrm{mg} \cdot \mathrm{L}^{-1}\right)$ and high level of IBA $\left(1.5 \mathrm{mg} \cdot \mathrm{L}^{-1}\right)$ induced callus. This study also indicated that the bursting time was not influenced by the auxin type ( 8 days). These results revealed that 2,4$\mathrm{D}$ at 0.1 and $0.5 \mathrm{mg.L^{-1 }}$ produced the highest induction rates (70 and $40.25 \%$ ) against $19.41 \%$ for IBA at $1.5 \mathrm{mg} . \mathrm{L}^{-}$ 1. Statistical analysis also showed that fresh and dry weight was significantly influenced by auxins type. The proliferation rate was significantly influenced by auxin type. All callus obtained during this study were white, friable for 2,4-D, and compact for IBA (Table 3).

\subsection{Effect of cytokinin in combination with $2,4-\mathrm{D}$ on callogenesis}

To assess the effect of cytokinin in combination with 2,4-D, three cytokinins: BAP; KIN and TDZ at four levels $\left(0.1 ; 0.5 ; 1.0\right.$ and $\left.1.5 \mathrm{mg}^{\mathrm{L} \mathrm{L}^{-1}}\right)$ were combined with $0.5 \mathrm{mg} \cdot \mathrm{L}^{-1}$ of $2,4-\mathrm{D}$. The results are recorded in Table 4 . These results showed that callus induction was significantly affected by the cytokinin in the presence of 2,4-D. In fact, all hormonal components induced callus. However, the combination 2,4-D $\quad\left(0,1 \mathrm{mg} \cdot \mathrm{L}^{-1}\right)$ with $\mathrm{KIN}\left(0,5 \mathrm{mg}^{\mathrm{L}} \mathrm{L}^{-1}\right)$ resulted in the highest induction rate (75.52\%). In addition, the callus obtained with this combination is greenish coloring and very friable favorable to somatic embryos production. MS medium containing $0.1 \mathrm{mg} \cdot \mathrm{L}^{-1} 2,4-\mathrm{D}$ and several concentration of TDZ induced callus with an induction rate varying from 29.73 to $45 \%$ according to the concentration. However, these callus are pasty texture unfavorable to produce somatic embryos. The induction rate, fresh and dry weight and proliferation rate were increased with $0.1 \mathrm{mg} \cdot \mathrm{L}^{-1} 2,4-\mathrm{D}+0.5 \mathrm{mg} \cdot \mathrm{L}^{-1} \mathrm{KIN} .2,4-\mathrm{D}$ associated with BAP promoted root formation, the callus is white and compact texture.

Table 3. Influence of auxin on cotton callus induction

\begin{tabular}{|c|c|c|c|c|c|c|c|c|}
\hline \multicolumn{2}{|c|}{$\begin{array}{l}\text { Auxin } \\
\left(\mathrm{mg} \cdot \mathrm{L}^{-1}\right)\end{array}$} & BT(D) & IR (\%) & $F W(m g \pm s)$ & $\mathrm{DW}(\mathrm{mg} \pm \mathrm{s})$ & PR (\%) & Color & Texture \\
\hline & 0.1 & 8 & $70.00 \pm 1.84 a$ & $2.80 \pm 0.66 a$ & $0.66 \pm 0.20 a$ & $21.27 \pm 1.58 b$ & white & friable \\
\hline & 0.5 & 8 & $40.25 \pm 0.96 b$ & $1.81 \pm 0.59 b$ & $0.23 \pm 0.08 b c$ & $22.21 \pm 1.42 b$ & white & friable \\
\hline \multirow[t]{2}{*}{$2,4 D$} & 1.0 & - & $0 \pm 0 d$ & $0 \pm 0 c$ & $0 \pm 0 c$ & $0 \pm 0 c$ & - & - \\
\hline & 1.5 & - & $0 \pm 0 d$ & $0 \pm 0 c$ & $0 \pm 0 c$ & $0 \pm 0 c$ & - & - \\
\hline
\end{tabular}




\begin{tabular}{|c|c|c|c|c|c|c|c|c|}
\hline & 0.1 & - & $0 \pm 0 d$ & $0 \pm 0 c$ & $0 \pm 0 c$ & $0 \pm 0 c$ & - & - \\
\hline & 0.5 & - & $0 \pm 0 d$ & $0 \pm 0 c$ & $0 \pm 0 c$ & $0 \pm 0 c$ & - & - \\
\hline \multirow[t]{4}{*}{ NAA } & 1.0 & - & $0 \pm 0 d$ & $0 \pm 0 c$ & $0 \pm 0 c$ & $0 \pm 0 c$ & - & - \\
\hline & 1.5 & - & $0 \pm 0 d$ & $0 \pm 0 c$ & $0 \pm 0 c$ & $0 \pm 0 c$ & - & - \\
\hline & 0.1 & - & $0 \pm 0 d$ & $0 \pm 0 c$ & $0 \pm 0 c$ & $0 \pm 0 c$ & - & - \\
\hline & 0.5 & - & $0 \pm 0 d$ & $0 \pm 0 c$ & $0 \pm 0 c$ & $0 \pm 0 c$ & - & - \\
\hline \multirow[t]{2}{*}{ AIB } & 1.0 & - & $0 \pm 0 d$ & $0 \pm 0 c$ & $0 \pm 0 c$ & $0 \pm 0 c$ & - & - \\
\hline & 1.5 & 8 & $19.41 \pm 1.20 c$ & $\begin{array}{l}2.13 \pm \\
0.65 a b\end{array}$ & $0.32 \pm 0.08 b$ & $70.2 \pm 1.47 a$ & white & compact \\
\hline
\end{tabular}

In column, means with the same letters are not significantly different at 5\%; T: Bursting time; D: Day; IR: Induction rate; FW: Fresh weight; DW: Dry weight; PR: Proliferation rate.

Table 4. Influence of cytokinin on cotton callus induction

\begin{tabular}{lllcccc}
\hline $\begin{array}{l}\text { Cytokinin } \\
\left(\mathbf{m g} \cdot \mathrm{L}^{-1}\right)\end{array}$ & BT & IR & FW & DW & PR & Color Texture \\
& (D) & (\%) & $(\mathbf{m g} \pm \mathbf{s})$ & $(\mathbf{m g} \pm \mathbf{s})$ & $(\%)$ &
\end{tabular}

\begin{tabular}{ccccccccc}
\hline & $\mathbf{0 . 1}$ & - & $0 \pm 0 c$ & $0 \pm 0 \mathrm{~b}$ & $0 \pm 0 \mathrm{~b}$ & $0 \pm 0 c$ & - & - \\
BAP & $\mathbf{0 . 5}$ & - & $0 \pm 0 c$ & $0 \pm 0 \mathrm{~b}$ & $0 \pm 0 \mathrm{~b}$ & $0 \pm 0 c$ & - & - \\
& $\mathbf{1 . 0}$ & - & $0 \pm 0 c$ & $0 \pm 0 \mathrm{~b}$ & $0 \pm 0 \mathrm{~b}$ & $0 \pm 0 c$ & - & - \\
& $\mathbf{1 . 5}$ & - & $0 \pm 0 c$ & $0 \pm 0 \mathrm{~b}$ & $0 \pm 0 \mathrm{~b}$ & $0 \pm 0 c$ & - & - \\
\hline & $\mathbf{0 . 1}$ & - & $0 \pm 0 c$ & $0 \pm 0 \mathrm{~b}$ & $0 \pm 0 \mathrm{~b}$ & $0 \pm 0 c$ & - & - \\
KIN & $\mathbf{0 . 5}$ & 21 & $23.75 \pm 0.70 \mathrm{~b}$ & $0.42 \pm 0.20 \mathrm{~b}$ & $0.06 \pm 0.03 \mathrm{~b}$ & $13.93 \pm 1.13 \mathrm{~b}$ & white & lit fr \\
& $\mathbf{1 . 0}$ & - & $0 \pm 0 c$ & $0 \pm 0 \mathrm{~b}$ & $0 \pm 0 \mathrm{~b}$ & $0 \pm 0 c$ & - & - \\
& $\mathbf{1 . 5}$ & - & $0 \pm 0 c$ & $0 \pm 0 \mathrm{~b}$ & $0 \pm 0 \mathrm{~b}$ & $0 \pm 0 c$ & - & - \\
\hline & $\mathbf{0 . 1}$ & - & $0 \pm 0 c$ & $0 \pm 0 \mathrm{~b}$ & $0 \pm 0 \mathrm{~b}$ & $0 \pm 0 c$ & - & - \\
& $\mathbf{0 . 5}$ & - & $0 \pm 0 c$ & $0 \pm 0 \mathrm{~b}$ & $0 \pm 0 \mathrm{~b}$ & $0 \pm 0 c$ & - & - \\
TDZ & $\mathbf{1 . 0}$ & 17 & $67.75 \pm 1.34 \mathrm{a}$ & $6.51 \pm 0.25 \mathrm{a}$ & $1.53 \pm 0.62 \mathrm{a}$ & $78.07 \pm 1.33 \mathrm{a}$ & yell-w & comp \\
& $\mathbf{1 . 5}$ & 17 & $69.05 \pm 1.3 \mathrm{a}$ & $7.53 \pm 0.59 \mathrm{a}$ & $1.79 \pm 0.56 \mathrm{a}$ & $71.53 \pm 1.70 \mathrm{a}$ & white & comp \\
\hline
\end{tabular}


In column, means with the same letters are not significantly different at 5\%; BT: Bursting time; D: Day; IR: Induction rate; FW: Fresh weight; DW: Dry weight; PR: Proliferation rate; yell-w: Yellowish white; lit fr: little friable; comp: compact.

\subsection{Effect of cytokinin in the presence of 2,4-D on callogenesis}

To assess the effect of cytokinin in combination with 2,4-D, three cytokinin: BAP; KIN and TDZ at four levels

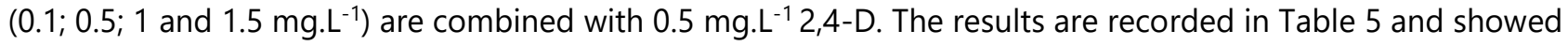
that callus induction was significantly affected by the cytokinin in the presence of 2,4-D.

Table 5. impact of cytokinin supplemented with $0.1 \mathrm{mg} / \mathrm{l}$ 2,4-D cotton callus induction

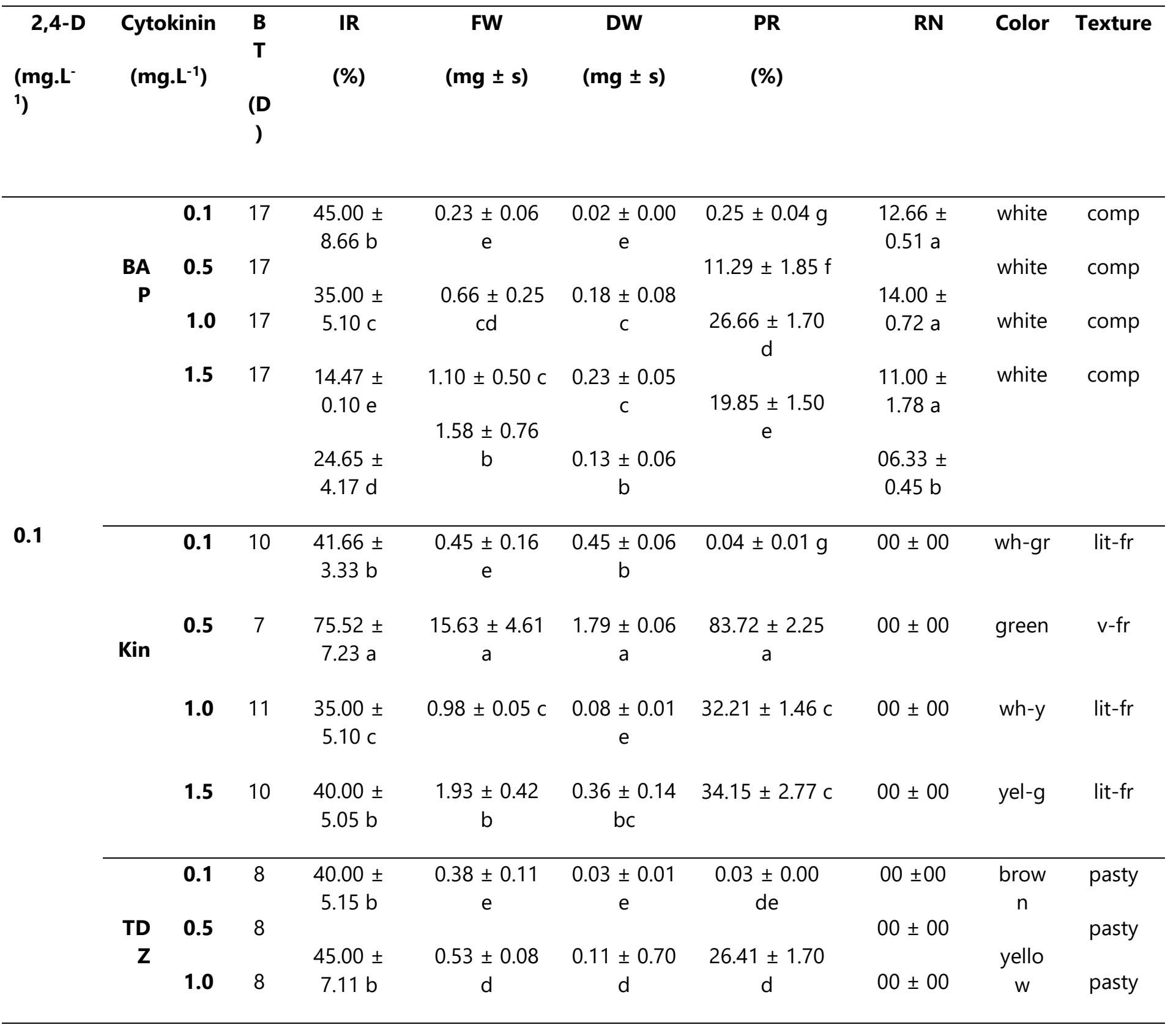




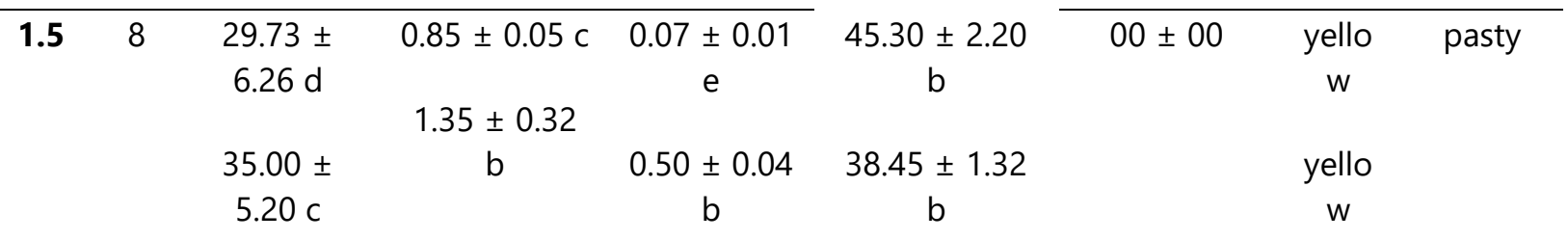

In the column, means with the same letters are not significantly different at 5\%; BT: Bursting time; D: Day; IR: Induction rate; RN: Root number; FW: Fresh weight;

DW: Dry weight; PR: Proliferation rate; why: whitish-yellow; wh-g: whitish green; yel-g: yellowish green; comp: compact; lit-fr: little friable; $v$-fr: very friable.

In fact, all hormonal components induced callus, but the combination 2,4-D (0.1 mg..-1) with KIN mg. $\left.\mathrm{L}^{-1}\right)$ resulted in the highest induction rate (75.52\%). In addition, the callus obtained with this combination is greenish coloring and very friable favorable to somatic embryos production. MS medium containing $0.1 \mathrm{mg} \cdot \mathrm{L}^{-1}$ of 2,4-D and several concentrations of TDZ induced callus with induction rate varied from 29.73 to $45 \%$ according to the concentration. However, these callus are pasty texture unfavorable to

produce embryos. The induction rate, fresh and dry weight and proliferation rate were increased with $0.1 \mathrm{mg} \cdot \mathrm{L}$ ${ }^{1}$ of 2,4-D + $0.5 \mathrm{mg}^{-\mathrm{L}^{-1}}$ of KIN. 2,4-D associated with BAP promoted root formation yet, the callus is white and compact texture (Figure 3).
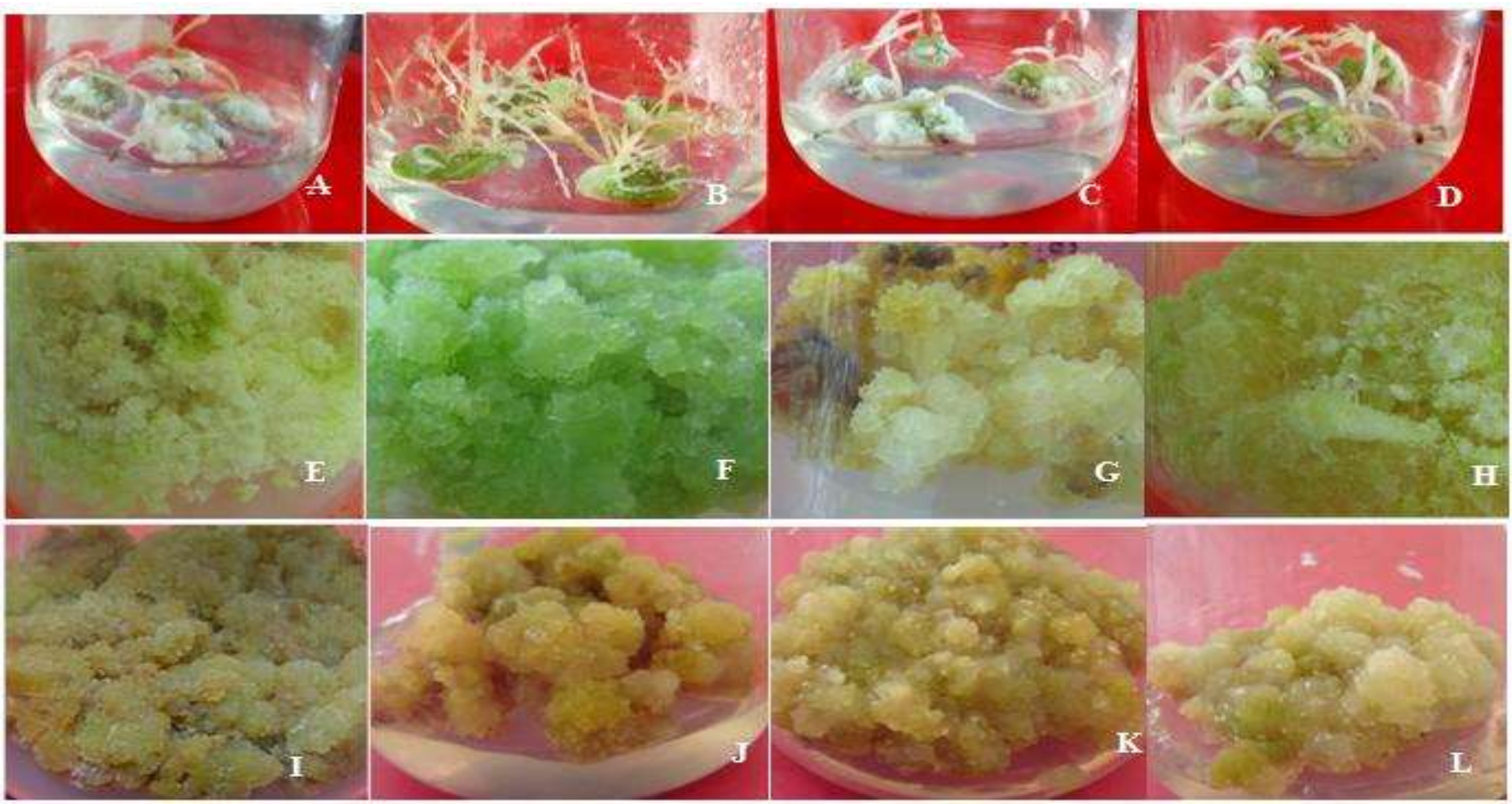

Figure 3. Cytokinin effect in the presence of 2,4-D on cotyledon callus

A: $0.1 \mathrm{mg} \mathrm{L}^{-1}$ of 2,4-D + $0.1 \mathrm{mg} \mathrm{L}^{-1}$ of BAP; $B: 0.1 \mathrm{mg} \mathrm{L}^{-1}$ of 2,4-D + $0.5 \mathrm{mg} \mathrm{L}^{-1}$ of BAP; $C: 0.1 \mathrm{mg} \mathrm{L}^{-1}$ of 2,4-D + $1 \mathrm{mg} \mathrm{L}^{-1}$ of BAP; D: $0.1 \mathrm{mg} \mathrm{L}^{-1}$ of ,4-D + $1.5 \mathrm{mg} \mathrm{L}^{-1}$ of BAP; $\mathrm{E}: 0.1 \mathrm{mg} \mathrm{L}^{-1}$ of 2,4-D + $0.1 \mathrm{mg} \mathrm{L}^{-1}$ of KIN; F: $0.1 \mathrm{mg} \mathrm{L}^{-}$ ${ }^{1}$ of 2,4-D + $0.5 \mathrm{mg} \mathrm{L}^{-1}$ of KIN; G: $0.1 \mathrm{mg} \mathrm{L}^{-1}$ of ,4-D + $1 \mathrm{mg} \mathrm{L}^{-1}$ of KIN; H: $0.1 \mathrm{mg} \mathrm{L}^{-1}$ of 2,4-D + $1.5 \mathrm{mg} \mathrm{L}^{-1}$ of KIN; 
I: $0.1 \mathrm{mg} \mathrm{L}^{-1}$ of 2,4-D + $0.1 \mathrm{mg} \mathrm{L}^{-1}$ of TDZ; J: $0.1 \mathrm{mg} \mathrm{L}^{-1}$ of 2,4-D + $0.5 \mathrm{mg} \mathrm{L}^{-1} \mathrm{TDZ} ; \mathrm{K}: 0.1 \mathrm{mg} \mathrm{L}^{-1}$ of 2,4-D + $1 \mathrm{mg}$ $\mathrm{L}^{-1}$ of TDZ, L: $0.1 \mathrm{mg} \mathrm{L}^{-1}$ of $2,4-\mathrm{D}+1.5 \mathrm{mg} \mathrm{L}^{-1}$ of TDZ .

\subsection{Effect of explant type on callogenesis}

In this experiment, three explants (root, hypocotyl, and cotyledon) were cultured on MS medium to assess their effect on callogenesis. The results revealed that callogenesis was significantly influenced by explant type (Table 6). So the response of callogenesis various according to the type explant. Thus, the bursting time was 7 for hypocotyl and cotyledon and 15 days for root explant. The result also showed that among the three explants, highest percentage of callus was obtained with hypocotyl (82.93\%), followed by cotyledon (68.75\%) and root (37.5\%). Statistical analysis indicated that fresh, dry weights of matter and proliferation rates were also significantly influenced by explant type. The highest fresh and dry weight of matter was produced by hypocotyl (24.41 and $1.98 \mathrm{mg}$ ). All callus are friable, and their color is brown, green and white respectively, for root, hypocotyl, and cotyledon (Figure 4).

Table 6. Effect of explant type on cotton callogenesis

\begin{tabular}{lccccccc}
\hline Explant & BT & IR (\%) & FW & DW & PR (\%) & Color & Texture \\
& (D) & & $\mathbf{( m g} \pm \mathbf{~ s )}$ & $\mathbf{( m g ~} \pm \mathbf{~ s )}$ & & & \\
& & & & & & \\
\hline root & 15 & $37.5 \pm 0.91 \mathrm{c}$ & $10.72 \pm 0.24 \mathrm{~b}$ & $0.35 \pm$ & 21.73 & brown & friable \\
& & & & $0.01 \mathrm{c}$ & $\pm 1.35 \mathrm{c}$ & & \\
& & & & & & & \\
\hline hypocot & 7 & $82.93 \pm$ & $24.41 \pm 0.67 \mathrm{a}$ & $1.98 \pm$ & $70.93 \pm$ & green & friable \\
yl & & $1.74 \mathrm{a}$ & & $0.08 \mathrm{a}$ & $1.14 \mathrm{a}$ & & \\
& & & & & & & \\
\hline cotyledo & 9 & $68.75 \pm$ & $12.8 \pm 0.17 \mathrm{~b}$ & $0.59 \pm 0.08$ & $55.14 \pm$ & white & friable \\
$\mathbf{n}$ & & $1.26 \mathrm{~b}$ & & $\mathrm{~b}$ & $1.64 \mathrm{~b}$ & & \\
& & & & & & & \\
\hline
\end{tabular}

In column, means with the same letters are not significantly different at 5\%; BT: Bursting time; IR: Induction rate; FW: Fresh weight; DW: Dry weight; PR: Proliferation rate.

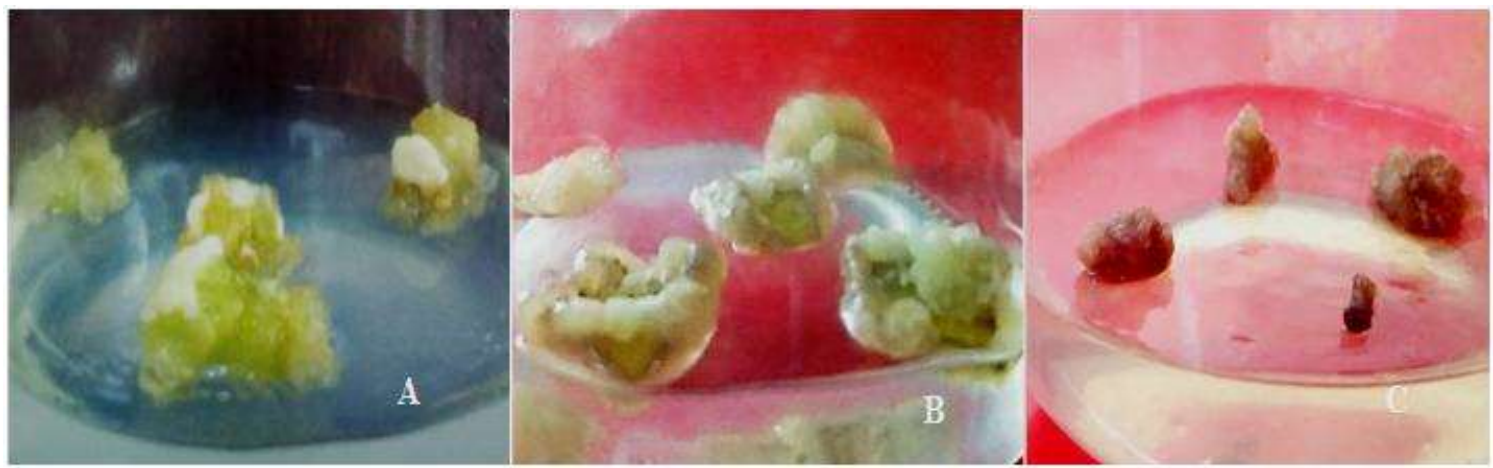

Figure 4. The response of cotton explant on callogenesis A: hypocotyl; B: cotyledon; C: root

\section{DISCUSSION}

Photosynthesis is very sluggish in vitro, indeed, several authors showed that sugar type is capital in culture medium because they permit tissue differentiation [19, 20]. However, tissue response differed according to medium component. Like this, our study revealed that sugar type was significant effect on cotton callogenesis. 
Similar results were obtained by Kouadio et al. [21] during their study on pineapple callogenesis. The results indicated that glucose produced the most friable and best callus than other sugars and presented the highest proportion of induction rate, fresh and dry weights of matter. Several authors reported that glucose produced high amounts of energy and it Is the most assimilated form of sugar type [13; 22]. The results also showed that glucose is followed by fructose, maltose, and sucrose. Similarly, Zouzou et al. [18] showed that glucose promoted cotton cell proliferation and it was followed by fructose, sucrose. Maltose given the least satisfactory results. However in our study, maltose induced more satisfactory results than sucrose. This difference would be linked to the variety studied. In addition, studies showed that the acid medium ( $\mathrm{pH}$ 5.8) trained sucrose hydrolysis in glucose and fructose. It induces a competition between these sugar types during their assimilation creating an inhibitory effect on callogenesis [23]. These results are in agreement with those of N'cho [5], which reported that sucrose practice an adverse effect on cotton callogenesis and this effect was linked to the low degradation of enzymes. The effect of sugar type depends of the plant material grow. Thus, unlike our study, Kouadio et al. [21] showed that sucrose was a better effect on pineapple callogenesis than other sugars. Other hand, Hakam et al. [24], indicated that maltose was more favorable to chickpea callus proliferation.

Glucose concentration also influenced callogenesis. Indeed, studies reported that high levels of glucose significantly affected cotton callogenesis. Statistical analysis showed that cell proliferation evolved in the same direction that glucose concentration. These results are in agreement with those of Buffard-Morel [25] and Rabéchault et al. [26]. Indeed, these authors have shown that the higher concentration of glucose increases osmotic pressure and promote the sugar and minerals absorption by explant.

The results also showed that at the low concentrations ( 2 and $3 \%$ ), the proliferation rate was 37.5 and $60.17 \%$, respectively. The callus obtained at these concentrations is friable, white, and green. These results are in conformity with different studies reported by many authors who showed that at $3 \%$ glucose induct friable callus [27-30].

Cotton callogenesis as in several other species is under the influence of sugar type, explant type, and hormonal components [31]. The result of auxin test indicated that low concentrations $\left(0.1\right.$ and $\left.0.5 \mathrm{mg} \mathrm{L}^{-1}\right)$ of 2,4-D stimulate callogenesis. While the highest concentrations have proved to be inhibitory. Similar results were also obtained by Naz and Khatoon [32] who showed during their studies on Achyranthes Aspera that the low concentrations of 2,4-D induce callogenesis. Also, Kheloufi [33] showed that 2,4-D is necessary in the medium culture for a better callogenesis responses in chickpea. The explant response on callogenesis varies on one hand according to species and from one party to another on the same species. Like this, ANA was showed unfavorable on cotton callus for all concentrations used. Similar results were obtained by Lachachi [34]. Indeed, this author showed that ANA did not produce callus and only 2,4-D induced tomato callogenesis. This study also showed that some cytokines are efficient to induce callogenesis. Thereby, $\mathrm{KIN}$ at $0.5 \mathrm{mg} \mathrm{L}^{-1}$ and high concentrations of TDZ ( 1 and $1.5 \mathrm{mg} \mathrm{L}^{-1}$ ) allowed callogenesis. These results confirm those of Ramadan et al. [35], which showed that cytokines practice a positive effect on cell sensitivity stirring an active cell proliferation. Several authors showed that cytokinines can induce callus in other species, such as pistachios and date palm. Indeed, the experiment of Houndonougbo [36] indicated that KIN stimulates cell proliferation and buds formation. So in the culture medium, KIN activates cell metabolism by increase the nucleic acid synthesis, and inhibiting root formation [37]. The highest induction rates were obtained with TDZ. However, this callus is compact and not promote somatic embryogenesis. According to Trolinder and Goodin [27], somatic embryogenesis starts when the tissue produces friable callus. The plausible explanation of callus induction by cytokinins would be that endogenous auxin could exist in cytokinin composition, giving them the ability to induce callus. According to several authors, in cotton culture, 2,4-D is an important hormone for callus growth [32], [38-40]. Thereby, to understand the effect of 2,4$\mathrm{D}$ on cotton callogenesis, three cytokinins at four levels $0.1,0.5,1.0$ and $1.5 \mathrm{mg} \mathrm{L}^{-1}$ were tested in combination with $0.1 \mathrm{mg} \mathrm{L}^{-1}$ of 2,4-D. The results showed that this combination promote cell proliferation. So the induction rate increased significantly in the presence of 2,4-D and the callus are friable. These results are in accordance with those of Zouzou et al. [41], who showed that low concentrations of 2,4-D supplemented with high concentrations of KIN in culture medium, stimulate callogenesis. Indeed, BAP alone not induced callus but promoted callogenesis in the presence of 2,4-D. In addition, this association stimulated root formation [42]. TDZ 
associated with 2,4-D induced pasty callus unfavorable to somatic embryogenesis. This pasty texture could be explained by the fact that there is an auxin activity with TDZ that allows this cytokinin to induce callus. Thus, the addition of 2,4-D seems to cause an excess of auxin, which would be responsible for the pasty texture of the callus. Abdullatif and Khalafallah [42], reported that another auxin such as NAA associated with KIN or BAP was used to induce callus. In this study, the three parts of plant (root, hypocotyl, and cotyledon) were cultured to evaluate their ability to induce callus. The result showed that the first callus formation was obtained with hypocotyl after seven days of culture. In addition, for all parameters studied, the highest induction rate was obtained by this explant [43; 44]. Similarly, several authors have reported that the induction and proliferation of callus in one species varies with explant type $[45,46]$. Thus, the type of explant would have an important influence on callus induction. Indeed, the explants have a reactivity or differential sensibility on culture medium [47]. Moreover, some authors have even reported an influence of the position and type of explant on callogenesis $[18,29,48]$. This material can be considered as an essential element that determines the success of the callogenesis. The search for favorable conditions for best callus induction seems to be a challenge in vitro culture. Indeed, the callus is a starting material for all different in vitro technique culture, including somatic embryogenesis [11].

\section{CONCLUSION}

The results obtained in this study based on medium and explants types effect on cotton callogenesis. They showed that the success of callogenesis depends on medium components and explants type. Indeed, our results showed that glucose at $3 \%$ allows obtaining the most voluminous and friable callus, favorable for somatic embryogenesis. In addition, $0.1 \mathrm{mg} \cdot \mathrm{L}^{-1} 2,4-\mathrm{D}$ combined with $0.5 \mathrm{mg} \cdot \mathrm{L}^{-1} \mathrm{KIN}$ promotes the callus induction and proliferation of cotton. Following to these results, cotton callus induction and cell proliferation were depended on sugar type, hormonal components, and explant type.

\section{REFERENCES}

1. Kouakou TH, Zouzou M, Kouadio YJ, Anno AP (2008). Embryogenèse somatique chez le cotonnier (Gossypium hirsutum L.): évolution des composés lipidiques au cours de la callogenèse et de la culture de suspensions cellulaires. Afr Sci 4(3): 147-159.

2. Sekloka E (2006). Amélioration de l'efficacité de la sélection pour le rendement en coton graine du cotonnier Gossypium hirsutum L. dans un contexte de nouveaux itinéraires techniques. Thèse de l'École Nationale Supérieure Agronomique de Rennes, France, 192p.

3. FAOSTAT (2016). Coton production par Pays Monde 2016. http://www.fao.org/3/a-BO104f.pdf. Accessed on 2018 May 5.

4. Anonymous (2018). Planetoscope-Statistique : Production mondiale de coton https://www.planetoscope.com/agriculture/1178-production-mondiale-de-conton.htm. Accessed

On 2018 May 2.

5. N'Cho X (2006). Callogenèse chez le cotonnier (Gossypium hirsutum L.): effets cultivar, nature et teneur en source de carbone. Mémoire DEA physiologie végétale, UFR biosciences, Université de Cocody, Abidjan, Côte d'Ivoire, 36p.

6. Coulibaly A (2015). Communication de la Côte d'Ivoire à la 74ème plénière du comité exécutif de coton (CCIC). Accessed on 2017 February 02.

7. Miranda JE, Rodrigues SMM, de Almeida RP, da Silva CAD, Togola M (2013). Reconnaissance de ravageurs et ennemies naturels pour les pays C-4. Empr Pesq Agrop 25: 74-93. 
8. Finer JJ, McMullen MD (1990). Transformation of cotton (Gossypium hirsutum L.) via particle bombardment. Plant Cell Rep 8: 586-589.

9. Wu J, Zhang $X$, Nie $Y$, Jin S, Liang S (2004). Factor affecting somatic embryogenesis and plant regeneration from a range of recalcitrant genotypes of Chinese cottons (Gossypium hirsutum L.). In Vitro Cell Biol 40: 371-382.

10. Yapo SES (2013). Propagation et régénération in vitro de l'ananas [Ananas comosus var. comosus $L$. (Merrill) Coppens \& Leal] cultivé en côte d'Ivoire et étude physicochimique des fruits issus des vitrocultures. Thèse de l'Université Nangui Abrogoua, Abidjan, Côte d'Ivoire, 151 p.

11. Kawtar L, Najat H, Brhadda N, Najat A, Gmira N, Elmustapha E, Tarik A, Benyahia H (2015). Optimisation de l'induction de callogenèse à partir des embryons excisés de mandariniers (Citrus spp.). J Appl Biosci 89: 8300-8310.

12. Kouadio OKS (2018). Effet de la composition du milieu de culture sur la régénération in vitro de l'ananas [Ananas comosus (L.) var. Cayenne lisse] par embryogenèse somatique indirecte et impact du stress salin sur les paramètres morphophysiologiques des vitroplants régénérés. Thèse de l'Université Nangui Abrogoua, Abidjan, Côte d'Ivoire, 206p.

13. Zouzou M, Kouakou TH, Koné M, Peeters MC, Swennen R (1997). Callogenèse chez le Cotonnier cultivé en Côte d'Ivoire: effets position explant hypocotyle, variété, source de carbone et régime hormonal. Afr Crop Sci Conf Proc 3: 1489-1494.

14. Murahige T, Skoog F (1962). A revised medium for rapid growth and bioassay with tobacco virus cultures. Physiol Plant 15: 473-497.

15. Gamborg OL, Miller RA, Ojima K (1968). Nutrient requirements of suspension cultures of soybean root cells. Exp Cell Res 50: 151-158.

16. Kouadio JY, Koné M, Djè Y, d'Almeida MA, Zouzou M (2004). L'étiolement est un facteur d'induction de l'embryogenèse somatique au cours de la callogenèse chez deux variétés récalcitrantes de cotonnier (Gossypium hirsutum L.) cultivées en Côte d'Ivoire. Biotechnol Agron Soc Env 8(3): 155-162.

17. Kouakou TH, Koné $D$, Zouzou $M$, Kouadio YJ (2007). Esterase isoenzymes are linked to embryogenic structures induction in cotton cell suspension cultures. Afr J Agr Res 2(8): 394-39.

18. Zouzou M, Kouakou TH, Koné M, Amani NG, Kouadio YJ (2008). Effect of genotype, explants, growth regulators and sugars on callus induction in cotton (Gossypium hirsutum L.). Aust J Crop Sci 2(1): 1-9.

19. Pierik RLM (1987). Commercial micropropagation in Western Europe and Israel. In Debergh P.C., Zimmerman R.H. Micropropagation technology application. Dordretch, the Netherlands: Kluwer Academic Publishers, pp 115-165.

20. Swankar P, Bohra SP, Chandra N (1986). Biochemical changes during growth and differentiation of the callus of Solanum surattense. J Plant Physiol 76: 75-81.

21. Kouadio OKS, Yapo ESS, Silue O, Adou BYC, Kouakou TH (2018). Influence of Carbohydrates on Callus Proliferation during Somatic Embryogenesis in Pineapple [Ananas Comosus (L.) Merry. (Bromeliaceae) Var. Cayenne Smooth Cultivar Cl 16]. Eur Sci J 14(15): 287-297.

22. Richter G (1993). Les glucides in Métabolisme des végétaux. Physiologie et brochure. Ed Presses Polytechniques et Universitaires. Romandes chap. IV, pp 189-220. 
23. Kouakou TH (1996). Effets composition et régime hormonal sur la callogenèse du le cotonnier (Gossypium hirsutum L. cv. ISA 205 N). Mémoire DEA Physiologie Végétale, UFR Biosciences, Université de Cocody, Abidjan, Côte d'Ivoire, 32 p.

24. HakamN, Sripada UM, Gaboun F, Rabha A, Ibriz M, Iraqi D (2014). Effect of genotypes and culture media on embryogenic callus induction and plantlet regeneration from mature embryos of durum wheat. Rom Agr Res 31: 121-128.

25. Buffard-Morel J (1968). Recherches sur la culture in vitro des embryons de palmier à huile. v. effets du glucose, du lévulose, du maltose et du saccharose. Oléagineux 23(12): 707-711.

26. Rabechault H, Buffard-Morel J, Vacheron C (1974). Recherches sur la culture in vitro des embryons de palmier à huile: effets de la pression osmotique sur la croissance et le développement et sur l'absorption des sucres. Oléagineux 29(12): 351-356.

27. Trolinder NL, Goodin JR (1988). Somatic embryogenesis in cotton (Gossypium). II. The requirement for embryo development and plant regeneration. Plant Cell Tiss Org Cult 12: 43-53.

28. Kouakou TH (2003). Contribution à l'étude de l'embryogenèse somatique chez le cotonnier (Gossypium hirsutum L.) : Évolution de quelques paramètres biochimiques au cours de la callogenèse et de cultures de suspensions cellulaires. Thèse de 3è cycle, Université de Cocody, Abidjan Côte d'Ivoire, 144p.

29. Haouala F, Farhat N, Chabchoub L (2010). Effets du type et de la position de l'explant sur l'induction de cals chez le gerbera (Gerbera jamesonii Bolus). Tropicultura 28(1) : 57-60.

30. Fotso MS, Donfagsiteli TN, Ndoumou DO (2008). Comparaison des premières étapes de l'embryogenèse somatique chez Baillonella toxisperma et Vitellaria paradoxa (Sapotacées). Biotechnol Agron Soc Env 12(2): 131-138.

31. Ren JP, Wang XG, Yin J (2010). Dicamba and sugar effects on callus induction and plant regeneration from mature embryo culture of wheat. Agr Sci Chin 9: 31-37.

32. Naz S, Khatoon K. 2014. The effect of auxins on callus induction in Achyranthes aspera. Pak J. Bot. 46(6): 2203-2207.

33. Kheloufi A (2006). Induction à la callogenèse chez quelques variétés de pois chiche (Cicer arietinum L.). Mémoire de Magister, Université d'Oran-Es Senia, Algerie, 38p.

34. Lachachi S (2010). Organogenèse et embryogenèse somatique directe chez la tomate. Mémoire de Magister, Université d'Oran-ES SENIA, Algerie, $117 \mathrm{p}$.

35. RamdanR., Handaji N, Beyahia H, Ibriz M (2014). Influence of growth regulators on callus induction from embryos of five citrus rootstocks. J Appl Biosci 73: 5959-5965.

36. Houndonougbo A (1989). Influence des différentes concentrations d'acide indole-3-acétique, d'acide naphtalène-acétique, $d$ 'acide 2,4-Dichlorophenoxyacétique et de kinétine sur la callogenèse et l'organogenèse in vitro de fragment d'entre nœud de deux variétés de patate douce (Ipomaea batatas L). Agronomy 9: 653-660.

37. Semiria $L$ (2013). Contribution à l'amélioration de l'Atriplex halimis par la culture de tissus in vitro. Mémoire de Magister, Université d'Oran-Es Senia, Algerie, 64p. 
38. Davidonis GH, Hamilton RH (1983). Plant regeneration from Callus tissue of Gossypium hirsutum L. Plant Sci Lett 32: 89-93.

39. Wang JY, Sun J, Hu J, Cui G (2004). Factors affecting the frequencies of callus induction and plantlet regeneration in maize immature embryo culture. Acta Agr Sin 30: 398-402.

40. Cao JL, Zhang XL, Jin SX, Yang XY, Zhu HG, Fu LL (2008). An efficient culture system for synchronization control of somatic embryogenesis in Cotton (Gossypium hirsutum L). Acta Agr Sin 34 (2): 224-231.

41. Zouzou M, Kouadio YJ, Koné M, Kouakou TH, Dénézon DO (2000). Callogenèse chez Gossypium hirsutum L.: effets cultivar, conditions de culture et type de matériel. Bioterre 1(1): 48-56.

42. Abdellatef $E$, Khalafallah, $M M(2008)$. Influence of growth regulators on callus induction from hypocotyls of medium staple cotton (Gossypium hirsutum L). Cultivar Barac B-67. J Soil Res Nat 2(1): 17-22.

43. Kamal GB, Zahra B, Behrooz A (2011). The effects of hormonal components of nutrient medium, cultivar, and explant type on cotton (Gossypium hirsutum L.) callus formation in vitro. J Appl Biosci 47: 32563263.

44. Kouakou HT, Kouakou LK, Kouassi MK, Koffi EK, Koné, M (2014). Influence de la taille des vitroplants et du type d'explant sur la réponse à la callogenèse chez le cotonnier (Gossypium hirsutum L.) cultivé en Côte d'Ivoire. Int J Biol Chem Sci 8(2): 588-595.

45. Ishii Y, Takamura T, Goi M, Tanaka M (2004). Callus induction and somatic embryogenesis of Phalaenopsis. Plant Cell Rep 17(6): 446-450.

46. Bahoya JAL (2012). Potentiel callogène et embryogène de trois génotypes de Theobroma cacao L. Mémoire de Magister, Université d'Oran-Es Senia, Algerie, 63p.

47. Kouakou TH (2009). Embryogenèse somatique chez le cotonnier [Gossypium hirsutum L.): variation des composés phénoliques au cours de la callogenèse et de la culture des suspensions cellulaires. Thèse d'État de l'Université d'Abobo-Adjamé, Abidjan, Côte d'Ivoire, 137p.

48. Tan ND, Thi TAT., Thi DHN, Trinh DN, Thanh HN, Quoc TN, Hong VN (2007). Effect of genotype, explant size, position, and culture medium on shoot generation of Gerbera jamesonii by receptacle transverse thin cell layer culture. Sci Hort 111: 146-151. 